\title{
亞酸化炭素に就 て（其二)
}

會 員屋弘

亞酸化炭素の製造 亞酸化炭素に限らす純䊀であり且つ試驗に使用する必要量 の試料を得ることは研究の第一であるが、卧酸化炭素は種々其存在を認められな がらも、其極めて不安定であり且つ純粹に得られ難く、混在する不純物は更に其 不安定度を促進するたや、 $\mathrm{C}_{3} \mathrm{O}_{2}$ を除いては其製法こして記述する程のものは未 だ發見せられて居ない。先づ第一に特筆せられるべき Brodie 氏の一酸化炭素を 出發物ざる方法は辛じて亞酸化炭素の存在を認識し得る程度のものに過ざない。 亞酸化炭素の構造及び性質等に解るっに到つたのは O. Diels 氏以來の事で、其 製法は數ある当有機酸或は其誘導顝を出發物をするもので何れる $\mathrm{C}_{3} \mathrm{O}_{2}$ に就てで ある。之等の方法は有機化學に屬するものばから故次に其鉒式を略記して其操作 に言及しないこと〉する。下記の中五酸化燐 $\mathrm{P}_{2} \mathrm{O}_{5}$ は他の有機「メステル」に及 ぼす作用と同じく脱水及じ分解作用をなするのである。

(I)<smiles>CCOC(=O)CCCCCCCC(=O)OCC</smiles>

(2)<smiles>CCOC(=O)CC(=O)OCC</smiles><smiles>O=C1OC2CC1C1OOCC21</smiles>
O. Diels.; B Wolf. (1) (1) 


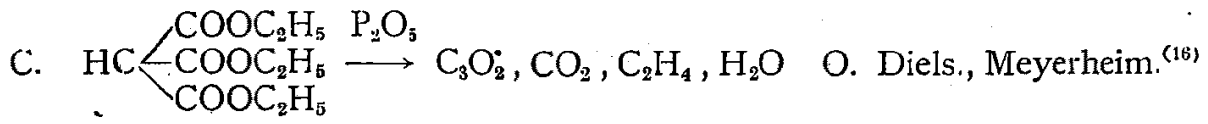

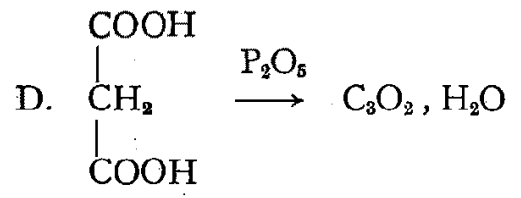

$\mathrm{COOH}$

(4) $\prod_{\mathrm{COOH}}^{\mathrm{CH}_{2}} \stackrel{\mathrm{P}_{2} \mathrm{O}_{5}}{\longrightarrow} \mathrm{C}_{3} \mathrm{O}_{2}, \mathrm{H}_{2} \mathrm{O}$

O. Diels., P. Blumberg. ${ }^{(17)}$

$\mathrm{COCl}$

(5)A. $\stackrel{\mathrm{CH}}{\mathrm{C}}_{2}^{\mathrm{Ag}} \mathrm{Ag}_{2} \mathrm{O}$ 攵 $\mathrm{PbO}$

$\mathrm{COCl}$

$\mathrm{C}_{3} \mathrm{O}_{2}, \mathrm{H}_{2} \mathrm{O}$

H. Staudinger., St. Bércza. ${ }^{(19)}$

A. Sock., H. Stolzen berg. (18)

$\mathrm{COCl}$

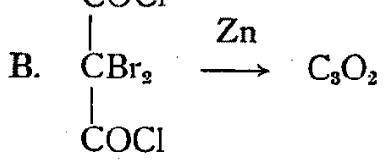

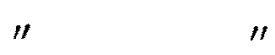

COCl

(6)

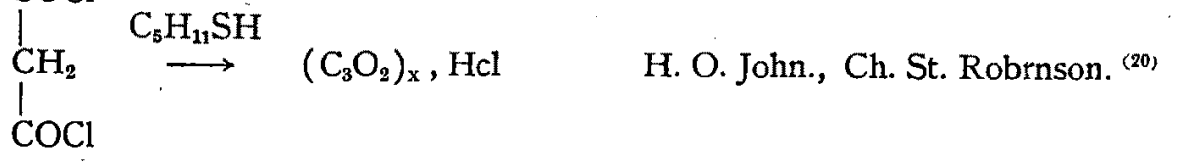

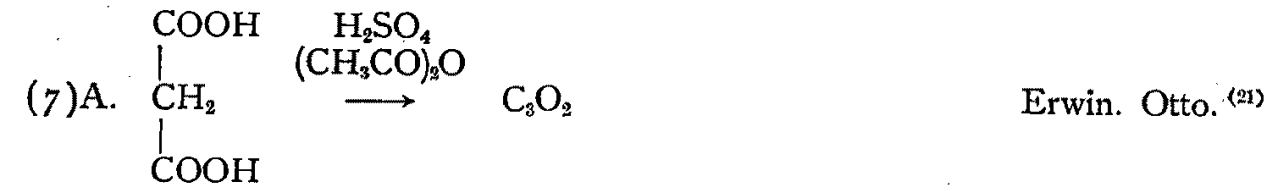

B. $\mathrm{CH}_{3} \cdot \mathrm{CO}_{2} \cdot \mathrm{CH}-\mathrm{CO}>\mathrm{O} \longrightarrow \mathrm{CH}_{3} \mathrm{COOH}+\underset{\mathrm{C}}{\mathrm{CH}_{3}} \underset{\mathrm{CO}}{\mathrm{CO}}-\mathrm{CO}$

C.

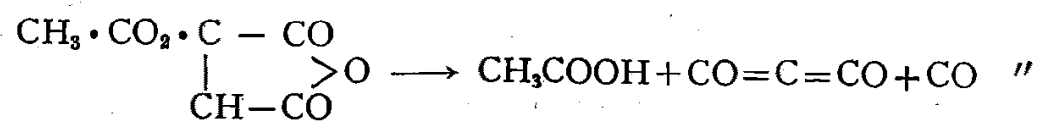

(8)

$\mathrm{CH}_{3} \cdot \mathrm{CO}_{2} \cdot \mathrm{CH}-\mathrm{CO}$

$\mathrm{CH}_{3} \cdot \mathrm{CO}_{2} \cdot \mathrm{CH}-\mathrm{CO} \mathrm{O} \longrightarrow \mathrm{C}_{3} \mathrm{O}_{2} \quad$ Erwin. Otto., Karl. Schmit. (22) 
$\mathrm{CH}_{3} \cdot \mathrm{CO}_{2} \cdot \mathrm{CH}-\mathrm{CO}$
$\mathrm{CH}_{3} \cdot \mathrm{CO}_{2} \cdot \mathrm{CH}-\mathrm{CO}>\mathrm{O} \longrightarrow \cdot{ }^{\mathrm{C}} \underset{\mathrm{CO}}{\mathrm{C}}>\mathrm{C}$

S. Redgroves ${ }^{(23)}$

性翼 前項に記した製法榡式き見るも $\mathrm{C}_{3} \mathrm{O}_{2}$ の構造及び性質の大略を察知する ここが出來る。 $\mathrm{C}_{3} \mathrm{O}_{2}$ は無色有毒の死斯體で刺諵性の不快な臭氮を有して居る。液

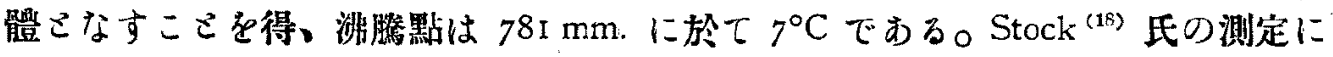

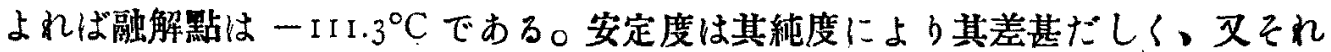
自身互に相反㮣する、即ち重合する。之は自己接觸作用によるこ考入られて居る。 要するに甚だ不安定で常温に於ても變化し易いものだある。1 $5^{\circ} \div 17^{\circ} \mathrm{C}$ に二日間 保てば重合して黑色の固體こなつた例があるが之は其試料が不純ですつた篇で、 現今までに最も純粹に製せられた E. Otto 氏の $\mathrm{C}_{3} \mathrm{O}_{2}$ は常温に於て三ヶ月間篮化 することなく、光線を遮斷して密閉硝子管中に保存すれば $20^{\circ} \mathrm{C}$ まで其存在を認 められたのである。

明確に知られて居る $\mathrm{C}_{3} \mathrm{O}_{2}$ の反應を大别して下記の二種さするここが出來る。

（1）化合力强大にして「ハロゲン」及び「ハロゲン」酸と添加物を作るのみな らず、水、アルコホル小「ネルカプタン」「アミン酸さも化合する。例を示せ ば次の如くである。

(a) $\mathrm{C}_{3} \mathrm{O}_{2}+2 \mathrm{H}_{2} \mathrm{O}=\mathrm{CH}_{2}(\mathrm{COOH})_{2}$

(b) $\mathrm{C}_{3} \mathrm{O}_{2}+2 \mathrm{C}_{2} \mathrm{H}_{5} \mathrm{OH}=\mathrm{C}_{\mathrm{C}} \mathrm{H}_{2}\left(\mathrm{COOC}_{2} \mathrm{H}_{5}\right)_{2}$

(c) $\mathrm{C}_{3} \mathrm{O}_{2}+2 \mathrm{NH}_{n}=\mathrm{H}_{2} \mathrm{C}\left(\mathrm{CO} \cdot \mathrm{NH}_{2}\right)_{2}$

(d) $\mathrm{C}_{3} \mathrm{O}_{2}+2 \mathrm{C}_{6} \mathrm{H}_{5} \mathrm{NH}=\mathrm{C}\left(\mathrm{CO} \cdot \mathrm{NH} \cdot \mathrm{C}_{6} \mathrm{H}_{5}\right)_{2}$

(e) $\mathrm{C}_{3} \mathrm{O}_{2}+2 \mathrm{CH}_{3} \mathrm{COOH}=\mathrm{CH}_{2}<\underset{\mathrm{COO} \cdot \mathrm{COCH}_{8}}{\mathrm{COO} \cdot \mathrm{COCH}_{3}}=\mathrm{CH}_{2}<\mathrm{CO}>\mathrm{O}+\left(\mathrm{CH}_{3} \mathrm{CO}\right)_{2} \mathrm{O}$

(2) 他の「ケテン」と結合する。 $\mathrm{C}_{3} \mathrm{O}_{2}$ は一種の「ケテン」と做すここを得り夫。 自身相互に結合するこきは所謂重合である。重合に就ては前號に述べた如く亞酸 化炭素の特性の一つである。製造の際混入し易い不純物 $\mathrm{P}_{2} \mathrm{O}_{5} 、 \mathrm{P}_{4} \mathrm{O}_{6} 、 \mathrm{CH}_{8} \mathrm{COOH}$ 等及び $\mathrm{C}_{3} \mathrm{O}_{2}$ 自身は此重合を促進する事實に疑了餘地がない。

此外「ケテン」の通性である所の酸素こ作用して添加物を作引同時に分解して 
二酸化炭素起生する事賽或は他の不佨和化合物さ結合して不能和結合手を充足す る傾向等に就ては遠からす分明せらるっものを考へらるっる、未だ $\mathrm{C}_{3} \mathrm{O}_{2}$ の構造

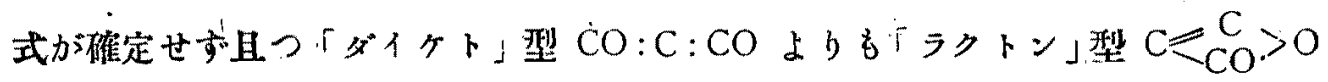
の方がー般に認めらるつ栐なれば、豫め速斷するを許さない。

$\mathrm{C}_{3} \mathrm{O}_{2}$ の棒造に關して O. Diels 氏一派の人々は $\mathrm{CO}: \mathrm{C}: \mathrm{CO}$ を固執し Michael 及び S. Redgroves 氏等は「ラクトン」型に有利な證明を與へて居る。實際化學 的性質よりは何れこも斷じ難く E. Otto 氏の實驗よりすれば $\mathrm{C}_{3} \mathrm{O}_{2}$ は最初の生成 に於て「ラクトン」型をなすを假定し、此物が直ちに「ダイケト」型に置換へら わるもとすれば說明が容易である。二三の物理恒數は後者に、燃燒熱は前者に 符合して居る。

$\mathrm{C}_{3} \mathrm{O}_{3}$ 以外の亞酸化炭素は前號に迅へし一二を除いては構造が全々不明であり、 性質に就ても不安定なるここ、重合し易きこと、「バイロヂエン双憵をなすこを 等が漠然こ推知し得るに過ざない。

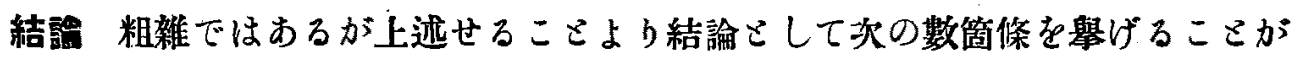
出爽る。即 5

(1) 亞酸化炭素は高温度に於ける縮合によつて一酸化炭素から生成する。

（2）此縮合生成物は二酸化炭素支發して酸素の割合のより少い亞酸化炭素さなる。

（3）亚酸化炭素は金屬酸化物に對して强力な還元作用を呈す。

（4）反應式 $2 \mathrm{CO}=\mathrm{CO}_{2}+\mathrm{C}$ に於て は亞酸化炭素の中間生成及び其分解の過程を諗 めるに充分論據がある。然し此反應の逆の方向に關して亞酸化炭素の過程は全々 末知である。

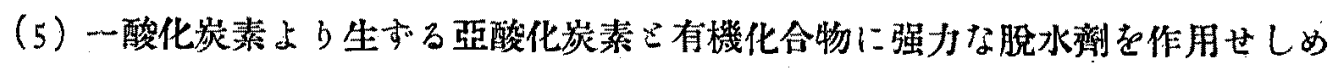
て生ずる酸化炭素この同一性が實證せられて居ない。

（6）有機酸の炭素原子の配列は之より得られて亞酸化炭素のそれと同一である。

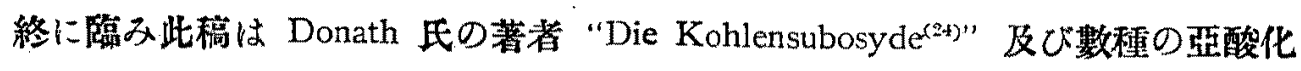
炭素の交献を讀みたる後の覺書に過ざすして至らざる所多し。諸賢の御敉示る得 
ば幸勘である。

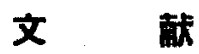

(I5) Ber. I906, 39, 1915; Ber. 1908, 41, 925.

(16) Ber. 1907, 40, 355.

(17) Ber. I908, 4I, 82.

(18) Ber. 1917, 50, I, 498.

(19) Ber. 1908, 4I, 4461.

(20) Journ. Chem. Soc. London. IOI, 935.

(21) Ber.' I914, 47, 2388.

(22) Ber. 1922, 55, 2126.

(23) Chem. News. 120, 209; 1 25, 35 I.

(24). Ed. Donath u. Otto Burian: Die Kohleusuboxyde. Verlag von Ferdinand Enke. 1924. 